\title{
Canopy Controls on the Forest- Atmosphere Exchange of Biogenic Ozone and Aerosol Precursors
}

\author{
ALEXANDER M. BRYAN AND ALLISON L. STEINER, PHD \\ Volume 1, Fall 2013 \\ DOI: http://dx.doi.org/10.3998/mjs.12333712.0001.005
}

\section{ABSTRACT}

Vegetation supports life on Earth, from supplying oxygen to the atmosphere to playing a role in the cycling of water. However, plants also emit natural or biogenic volatile organic compounds (BVOCs). BVOCs are an important precursor to the formation of tropospheric ozone- a compound that can adversely affect air quality, human health, and the environment—yet there are many outstanding questions regarding the emission and flux of BVOCs from the forest to the atmosphere. This review synthesizes recent research results pertaining to forest-atmosphere exchange, including the formation and fate of primary biogenic ozone precursors and the key physical and chemical processes occurring within and above vegetation canopies that control the efficient exchange of gases. Knowledge of these processes can improve our understanding of the forested environment and its role in sustainable air quality. We conclude from this review that, while we have a deep understanding of a vast array of processes that regulate BVOC emissions to the atmosphere on a local level, how those processes feedback to regional-scale air quality and climate is less understood. A synthesis of data from a wide variety of forest sites may help improve our understanding of the role of forests on air quality and climate and allow policy makers to make informed decisions with respect to maintaining sustainable air quality and climate.

\section{Introduction}

Terrestrial vegetation plays a critical role in sustainable air quality and climate. To protect against a variety of stresses, plants release gases known as volatile organic 
compounds (VOCs), which impact air quality and climate indirectly as precursors of ozone $\left(\mathrm{O}_{3}\right)$ (Logan 1985) and particulate matter (Carlton, Wiedinmyer, and Kroll 2009; Hallquist et al. 2009). While beneficial in the upper atmosphere for protecting life on Earth from solar ultraviolet radiation, ozone is toxic to humans and plants and thus undesirable in large amounts near the Earth's surface. Particulate matter reflects sunlight back to space, resulting in a cooler climate; it also contains pollutants that induce respiratory problems in humans.

Biogenic VOCs (BVOCs) emitted naturally from vegetation account for more than $80 \%$ of the global VOC budget (Guenther et al. 2006) and thus have the potential to affect air quality on a global scale. However, ozone formation requires an additional precursor of primarily anthropogenic origin (Logan 1985); thus, unsustainable air quality problems are most frequent in heavily populated and industrialized urban centers (Carslaw and Carslaw 2001). BVOCs can aggravate regional air quality problems, as observed in vegetated urban areas like Atlanta (Chameides et al. 1988) and in forests downwind of urban areas (Carroll, Bertman, and Shepson 2001; Sillman et al. 2002; Day et al. 2009; Bryan et al. 2012). As urbanization continues, ozone problems are expected to rise unless regulations on anthropogenic emissions are implemented (Bloomer et al. 2009). In addition, climate and landuse change are expected to exacerbate global ozone- and aerosol-induced air quality problems by enhancing VOC emissions (Steiner et al. 2006; Heald et al. 2008). Deforestation and land-use change associated with urban and agricultural expansion, however, will reduce BVOC emissions globally (Heald et al. 2008). Despite these changes in BVOC levels from human activity, ozone concentrations may increase or decrease depending anthropogenic precursors (Steiner et al. 2006). Understanding the complex interplay between biogenic and anthropogenic ozone precursors is critical for implementing effective policy legislation aimed at mitigating ozone problems.

While we understand the potential impacts of climate, land use, and social change on future air quality qualitatively, an improved understanding of the role of biogenic VOCs in ozone formation is needed to provide policy makers with an accurate, quantitative assessment of future change to better inform policy decisions. Models adequately simulate ozone formation in urban areas, where ozone concentrations can reach unsustainable levels due to anthropogenic emissions from industrial activity (Sillman 1999; Carslaw and Carslaw 2001). However, model applications to remote vegetated environments reveal gaps in our understanding of the role of VOCs in the formation of ozone and particulate matter (Lelieveld et al. 2008; Ganzeveld et al. 2008). These findings suggest that more VOC oxidation and thus more ozone formation may occur in forest environments than is presently simulated, which leads to 
inaccurate projections of future air quality and climate that may misinform pollution mitigation legislation. Improving our understanding of the role of biogenic VOCs in ozone and particular matter formation requires an improved understanding of the physical and chemical processes occurring within and above forest canopies that influence VOC concentrations and exchange across the forest-atmosphere boundary.

The extent to which BVOCs can interact with anthropogenic ozone precursors to influence regional ozone problems depends on how much VOC escapes the canopy in a process known as forest-atmosphere exchange. Several physical and chemical processes occurring within and above forest canopies control the exchange of BVOCs into the atmosphere. This review offers a characterization of these processes and the need for future research. In the next section, we describe the individual processes that drive the production, removal, and movement of BVOCs within and above the forest canopy. Then we synthesize a suite of recent observational field campaigns and modeling studies to summarize the current knowledge of the processes and their influence on BVOC concentrations and fluxes out of the forest canopy. Finally, we offer directions for future research that would enhance our understanding of exchange across the canopy-atmosphere interface and its role in sustainable air quality.

\section{Canopy Processes and Their Effects on BVOCs}

Exchange of BVOCs across the forest-atmosphere boundary is controlled by the interactions between the vegetation and the surrounding air. Leaves in the canopy emit and take up gases directly, and the fate of these compounds in the atmosphere is affected by photochemical destruction and transport within and out of the canopy airspace. These processes (emission, deposition, chemistry, and turbulent transport) are the primary controls on forest-atmosphere exchange. Emission and deposition denote fluxes into and out of the atmosphere, respectively. After emission, chemistry in the atmosphere drives the transformation of BVOCs to ozone. Once BVOCs are emitted from the canopy foliage, atmospheric turbulence transports and mixes them within the atmospheric boundary layer.

\section{BVOC Emission from Vegetation Foliage}

Plants generate terpenes - a class of BVOC of the form $\mathrm{C}_{5 \mathrm{x}} \mathrm{H}_{8 \mathrm{x}}$ (e.g., $\mathrm{C}_{5} \mathrm{H}_{8}, \mathrm{C}_{10} \mathrm{H}_{16}$, etc.) - for a variety of physiological purposes (Fuentes et al. 2000; Sharkey, Wiber- 
ley, and Donohue 2008). Isoprene $\left(\mathrm{C}_{5} \mathrm{H}_{8}, 2\right.$-methyl-1,3-butadiene), generated predominantly by broadleaf vegetation such as oak and aspen (Guenther, Zimmerman, and Wildermuth 1994; Kesselmeier and Staudt 1999), is thought to protect leaves against large heat stresses resulting from direct and prolonged exposure to intense sunlight (Sharkey and Singsaas 1995). In addition, isoprene consumes ozone and other reactive oxygen, protecting vegetation against oxidation of foliage tissue (Loreto and Velikova 2001). Needle-leaf vegetation (e.g., pine, spruce, and fir) produce monoterpenes $\left(\mathrm{C}_{10} \mathrm{H}_{16}\right)$ to attract pollinators with their pine scents (Dudareva and Pichersky 2000), defend against insects and other herbivores (Phillips and Croteau 1999), and inhibit growth of competing vegetation within the same nutrient pool (Muller 1966). Larger terpenes (e.g., sesquiterpenes, $\mathrm{C}_{15} \mathrm{H}_{24}$ ) formed by plants undergo rapid chemical destruction after being emitted into the atmosphere; thus their degree of influence in gas-phase atmospheric chemistry is not well known. Isoprene and monoterpenes (collectively referred to as isoprenoids) are the focus of most studies, as they are emitted in large quantities and account for $44 \%$ and $11 \%$ of total global VOC, respectively (Guenther et al. 1995; Steiner and Goldstein 2007). Regionally, however, isoprenoid emission abundances vary by plant species and geographical location due to several variables that control their formation and emission into the atmosphere.

Plants synthesize BVOCs from the carbon gained during photosynthesis at a rate proportional to light and temperature (Fall and Wildermuth 1998; Loreto et al. 1996). Following synthesis, BVOCs vaporize at a temperature-dependent rate and subsequently diffuse across cell membranes and through the leaf pores, or stomates, into the atmosphere (Lerdau, Guenther, and Monson 1997). Isoprene emits promptly after synthesis in the chloroplasts of broadleaves, whereas needleleaf vegetation stores a substantial fraction of monoterpenes in resin vessels (Lerdau, Guenther, and Monson 1997). Accordingly, isoprene emits following its light- and temperature-dependent synthesis rate (Tingey et al. 1979; Monson et al. 1992; Sharkey et al. 1996), whereas monoterpene emissions generally follow their temperature-dependent rate of vaporization (Guenther, Monson, and Fall 1991). Some Mediterranean oaks, however, exhibit a light-dependent monoterpene emission (Loreto et al. 1996). As a result of the light-dependent emission of isoprene, near-canopy concentrations tend to follow the sunlight diel cycle (Figure 1). Other factors such as plant physiology (e.g., stomatal conductance), leaf age, prior temperature history, and soil moisture are also known to affect or control the emission of isoprene and monoterpenes (Fall and Monson 1992; Guenther et al. 2006; Tawfik et al. 2012). Herbivore attack (Phillips and Croteau 1999) or extreme leaf tempera- 


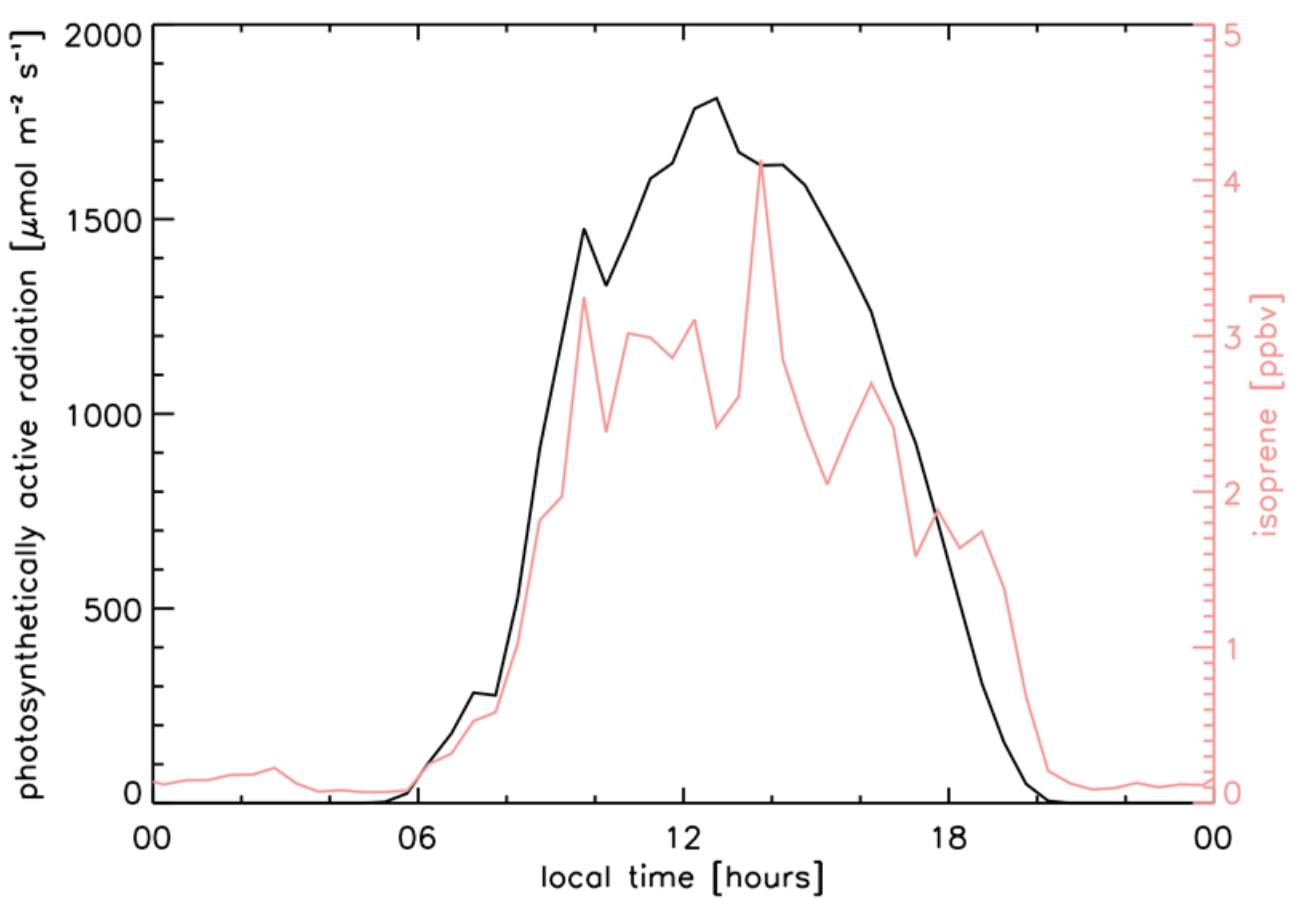

Figure 1: Diel cycle of photosynthetically active radiation (black) and isoprene concentration (red) measured within the canopy under clear-sky conditions. Data for 28 July 2009 during the CABINEX field campaign at the University of Michigan Biological Station, courtesy of Barry Lefer (University of Houston) and Tom Jobson (Washington State University).

ture change may also trigger short bursts in BVOC emission (Sharkey, Wiberley, and Donohue 2008).

\section{Oxidation of BVOCs in the Atmosphere}

Once emitted into the atmosphere, primary BVOCs are subjected to oxidation via reaction with one of three main tropospheric oxidants: the hydroxyl radical $(\mathrm{OH})$, ozone $\left(\mathrm{O}_{3}\right)$, or the nitrate radical $\left(\mathrm{NO}_{3}\right)$. OH is produced in the presence of sunlight, whereas nitrate is easily destroyed by incoming solar radiation. Therefore, the $\mathrm{OH}$ and nitrate radicals are the main drivers of daytime and nighttime VOC oxidation, respectively, in the free atmosphere (i.e., above the forest canopy). In the canopy, however, shading by vegetation foliage and branches reduces photochemical $\mathrm{OH}$ production and $\mathrm{NO}_{3}$ destruction, thus increasing the influence of nitrate as a VOC sink even during the day (Fuentes et al. 2007). Observations and models indicate that $\mathrm{NO}_{2}$ photolysis (i.e., the destruction of $\mathrm{NO}_{2}$ by sunlight) is also 
reduced within the canopy (Figure 2), lowering the potential for ozone formation while increasing daytime $\mathrm{NO}_{3}$ production. As direct sunlight attenuates through the canopy, diffuse radiation from the reflection of light off leaves and aerosols becomes a major driver of in-canopy photochemistry, accounting for up to $85 \%$ of in-canopy radiation (Knohl and Baldocchi 2008).

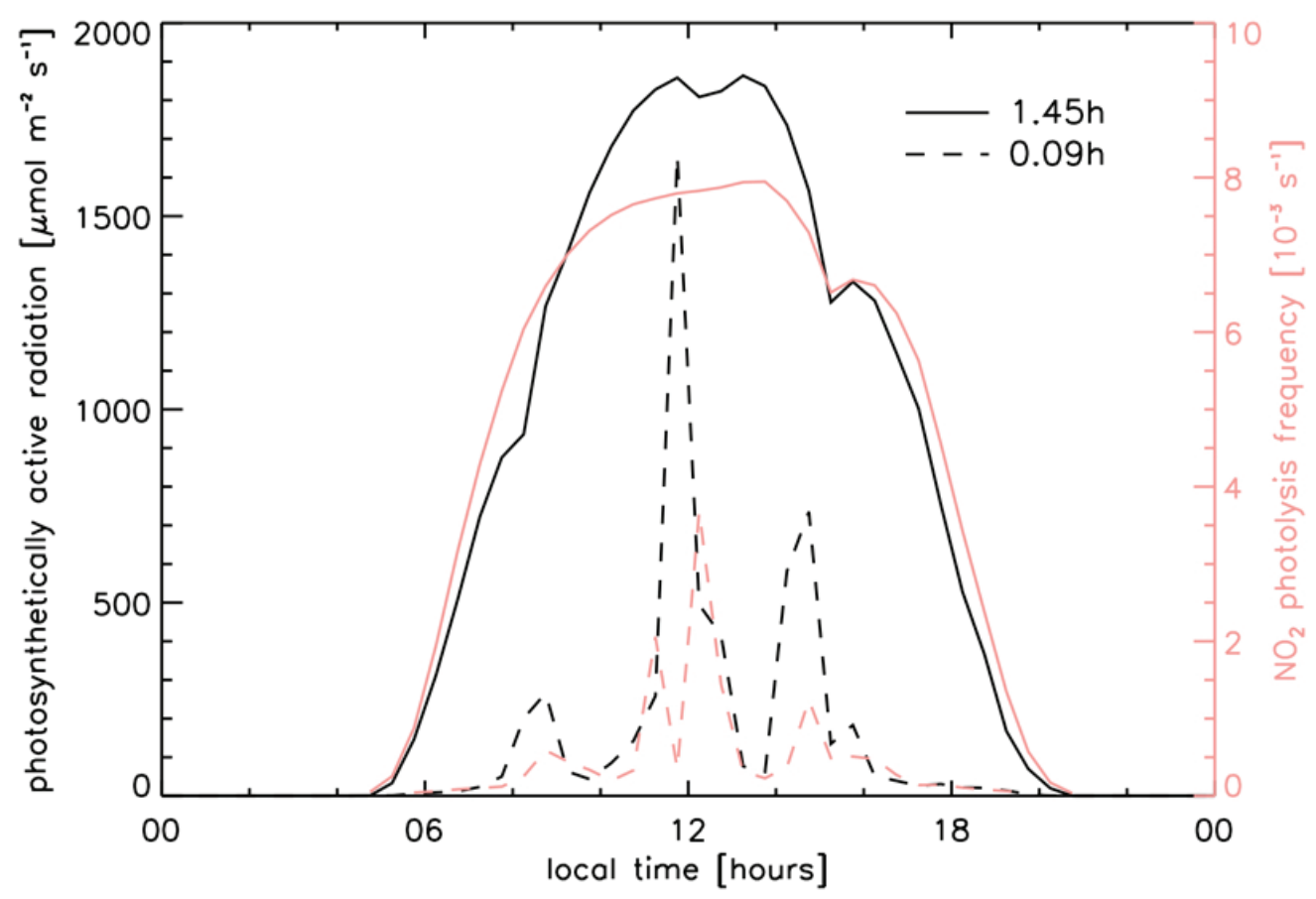

Figure 2: Photosynthetically active radiation (i.e. radiation in the $0.4-0.7 \mu \mathrm{m}$ waveband, or visible light, black) and $\mathrm{NO}_{2}$ photolysis frequency (red) above (1.45 times the canopy height, solid) and below (0.09 times the canopy height, dashed) the canopy along the PROPHET flux tower, located within the mixed hardwood forest in northern Michigan.

Oxidation in the atmosphere occurs on the order of seconds to days depending on several factors (Steiner and Goldstein 2007). The chemical lifetime depends on the oxidation pathway, which is variable depending on the chemical structure of the BVOC species and the availability of oxidants. Because isoprene is the most abundantly emitted BVOC and $\mathrm{OH}$ is the most reactive oxidant, the isoprene-OH oxidation pathway is the most influential mechanism driving BVOC chemistry and the formation of ozone precursors. Ozone has a particular affinity for compounds 
with double bonds and is therefore a dominant oxidant for the larger terpenes (e.g., monoterpenes and sesquiterpenes) (Steiner and Goldstein 2007).

The oxidation of primary BVOC emissions (e.g., isoprene and monoterpenes) forms a suite of secondary products known as oxygenated VOCs, including formaldehyde $\left(\mathrm{CH}_{2} \mathrm{O}\right)$, methacrolein $\left(\mathrm{C}_{4} \mathrm{H}_{6} \mathrm{O}\right)$, methyl vinyl ketone $\left(\mathrm{C}_{4} \mathrm{H}_{6} \mathrm{O}\right)$, and various additional peroxy radicals. Further oxidation of these secondary products forms the hydroperoxyl radical $\left(\mathrm{HO}_{2}\right)$, a primary atmospheric oxidant and dominant ingredient for tropospheric ozone. In addition to the formation of $\mathrm{HO}_{2}$, oxygenated VOCs can also react with radicals to produce less volatile species that plants often take up, as discussed below.

\section{BVOC Uptake by Plants and Deposition onto Surfaces}

Many BVOCs and other airborne gases interact with the Earth's surface in a variety of ways. Gases may settle on the ground or other surfaces by gravity. Raindrops often collect and carry gases to the surface. In addition, plants take up gases through their stomata in a process known as stomatal uptake. These mechanisms are all forms of deposition, a process that removes gases from the atmosphere. Deposition rates vary by gas, as well as vegetation architecture and the ambient meteorology. Due to their low mass and solubility, BVOCs rarely deposit via gravitational settling or capture by rain. Higher concentrations of primary BVOCs (isoprene and monoterpenes) exist within leaves than in the surrounding atmosphere, which is more conducive to emission than to stomatal uptake. Oxidized BVOCs (e.g., formaldehyde and methacrolein), on the other hand, are more highly concentrated in the atmosphere than within leaves and are thus susceptible to stomatal uptake.

Stomatal uptake occurs when atmospheric concentrations immediately adjacent to a leaf exceed those within the leaf, which allows the diffusion of molecules into the leaf structure. For example, plants take up carbon dioxide $\left(\mathrm{CO}_{2}\right)$ via stomatal uptake for photosynthesis. Ozone and sulfur dioxide $\left(\mathrm{SO}_{2}\right)$ are widely recognized as having among the highest deposition efficiencies via plant uptake (Wesely 1989; Finkelstein et al. 2000; Hogg et al. 2007). Once taken up by the plant, ozone damages the leaf by oxidizing the tissue. Some studies postulate that plants protect themselves from ozone exposure by emitting BVOCs that react with the ozone in the air immediately surrounding the leaf (Sharkey, Wiberley, and Donohue 2008). Recent studies also show that products of isoprene oxidation (e.g., formaldehyde, methacrolein, and methyl vinyl ketone) that oxidize into ozone-forming peroxy 
radicals deposit at rates comparable to or up to 2-3 times greater than that of ozone (Karl et al. 2010; Sumner et al. 2001).

\section{Turbulence-Driven Transport of BVOCs in the Atmosphere}

Wind shear and heating-induced convection result in the formation of turbulent eddies in the lower atmosphere (Stull 1988). These turbulent eddies mix BVOCs and their oxidation products throughout the atmospheric boundary layer, providing the dominant physical mechanism driving forest-atmosphere exchange. While molecular diffusion also transfers BVOCs from the canopy to the atmosphere, turbulence is substantially more efficient and thus diffusion is typically neglected in atmospheric models. The effect of turbulent mixing on atmospheric concentrations of gases depends on the chemical lifetime of a gas (Molemaker and de Arellano 1998; Krol, Molemaker, and de Arellano 2000). Long-lived gases (e.g., oxygen, carbon dioxide, and methane) tend to be distributed uniformly in the planetary boundary layer (i.e., are "well-mixed") and thus turbulence has little effect on their concentrations. In contrast, short-lived gases such as oxidants (e.g., $\mathrm{OH}$ and nitrate) react before turbulence can transport them very far. BVOCs have a chemical lifetime that is approximately the same order as their turbulent timescale (generally minutes to hours). Consequently, the efficiency of forest-atmosphere BVOC exchange is highly sensitive to turbulent strength, especially during the daytime (Bryan et al. 2012). Therefore, while most atmospheric chemistry models may adequately capture gas exchange across the land-atmosphere boundary, models simulating BVOC exchange may require more detailed turbulence parameterizations.

Turbulent strength, typically represented in atmospheric models by the turbulent exchange coefficient $(K)$, varies with altitude and time of day. The turbulent exchange coefficient for heat $\left(K_{\mathrm{H}}\right)$ shown in Figure 3 serves as a reliable proxy for the strength of turbulence that is responsible for the exchange of atmospheric gases. Turbulence peaks in the mid-afternoon around the middle of the planetary boundary layer ( $-500 \mathrm{~m}$ above ground level). In the lower portion of the boundary layer, turbulence strength weakens with decreasing altitude as a result of frictional drag induced by the Earth's surface. Near the forest canopy layer $(-20 \mathrm{~m})$, daytime turbulence as estimated by $K_{\mathrm{H}}$ is weaker than in the mid-boundary layer by approximately two orders of magnitude. This reduction in turbulence strength near the surface layer partially accounts for the similarity in timescales between turbulence-induced exchange and chemical degradation of BVOCs within forest canopies noted above.

The nature of turbulence within forest canopies is complex due to the presence 


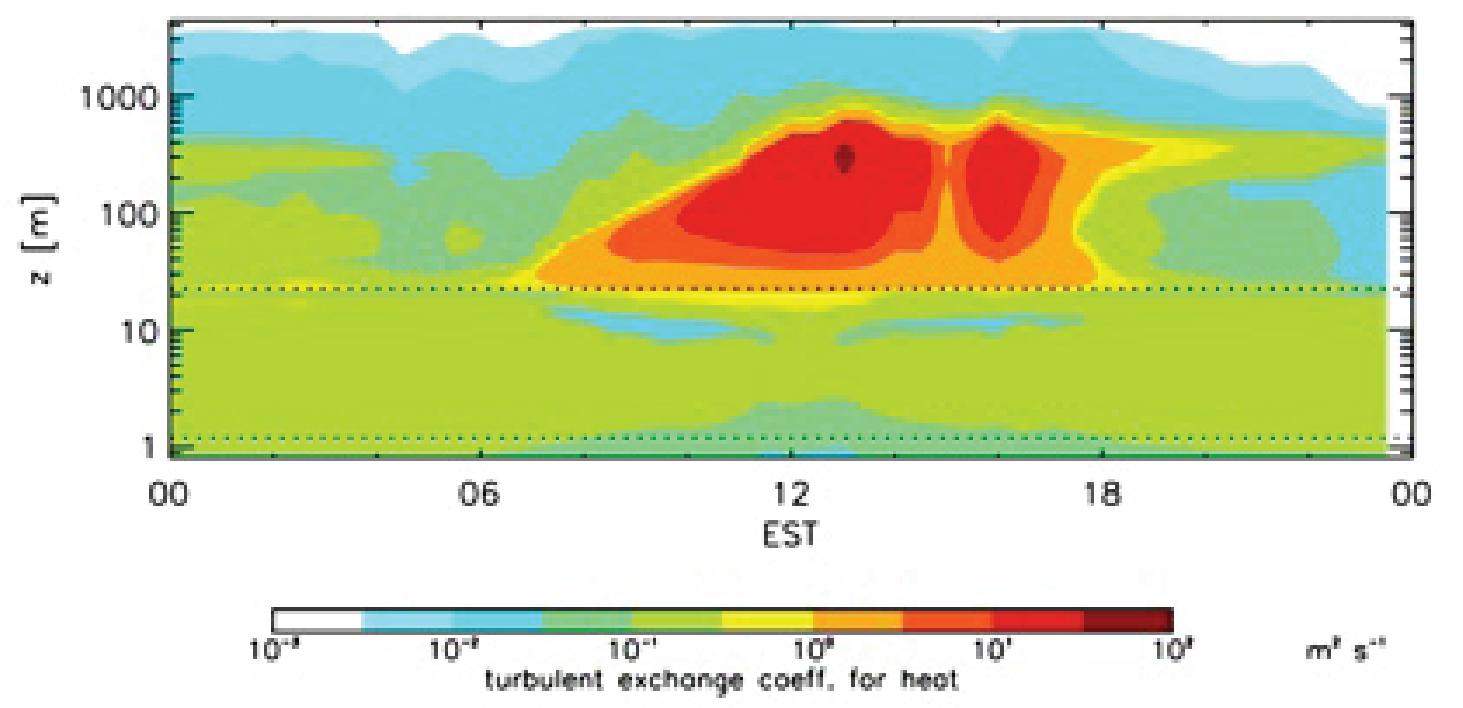

Figure 3: Simulated diel cycle of turbulent exchange coefficient for heat $\left(K_{\mathrm{H}}\right)$ as simulated by the Canopy Atmospheric Chemistry Emission (CACHE) model. The dashed lines represent the upper and lower limits of the foliage canopy. Model simulations are based on the input of photosynthetically active radiation measured during a typical sunny day at the University of Michigan Biological Station.

of vegetation. Foliage, branches, and other sources of roughness induce aerodynamic drag, perturbing and weakening dynamic motions and movement of gases in the canopy airspace (Baldocchi and Meyers 1988). The strength of frictional drag varies widely with canopy structure, in particular with respect to foliar density as well as the heterogeneous nature of the canopy. Closed (or dense) canopies exhibit particularly slow fluxes of BVOCs across the forest-atmosphere boundary in large part due to the physical obstruction of canopy elements.

As a consequence of the relatively weak background turbulence within and below forest canopies, in-canopy motions are particularly sensitive to other dynamical perturbations. Intense bursts of turbulent activity known as coherent structures (Collineau and Brunet 1993a; Finnigan 2000; Steiner et al. 2011) occur in two common forms: (1) rapid streams of downward motion that pass through the canopy layer known as "sweeps" and (2) subsequent upward motions known as "ejections" (Raupach, Finnigan, and Brunet 1996). These erratic motions may be critical for the efficient exchange of BVOCs out of the canopy layer given the weak nature of in-canopy turbulence. Unfortunately, due to the brief (lasting on average 5-7 seconds), intermittent (occurring at uneven intervals ranging from 15-75 seconds), and unpredictable nature of these events (Collineau and Brunet 1993b), 
these events are typically filtered from observational datasets via time averaging as part of data analysis and neglected in atmospheric models. Consequently, correlating BVOC fluxes with coherent structure events is still an area of active research, and the effects of these phenomena on forest-atmosphere BVOC exchange are not yet well understood.

\section{Current and Future Research Applications of Forest-Atmosphere BVOC Exchange}

Considerable research has focused on forest-atmosphere BVOC exchange through a number of observational field campaigns at flux towers in the United States (e.g., CABINEX, Bryan et al. 2012; BEARPEX, Wolfe et al. 2011; CELTIC, Stroud et al. 2005; and BEACHON, DiGangi et al. 2011). The diverse array of vegetation types covered by these studies allows for the examination of both isoprene- and monoterpene-dominated sites. Often coupled with modeling studies, these campaigns may reveal discrepancies between simulated and observed conditions that illuminate gaps in our knowledge of canopy processes and provide possible directions for future research. Here, we present some of the current research activities and remaining outstanding questions with respect to the canopy processes discussed above.

Foliar emissions of BVOCs, particularly of isoprene, have been studied extensively over the past few decades, yet large uncertainties in observed emission rates have yet to be explained (Smiatek and Steinbrecher 2006). While day-to-day BVOC emissions have a distinct light and temperature dependence, emission rates vary in complex ways that are not well characterized (e.g., tree age, temperature history, and soil moisture). Vertically heterogeneous canopies, such as the mid-successional forest of the University of Michigan Biological Station located at the northern tip of Michigan's lower peninsula, exhibit a diverse array of biogenic emissions along with vertically varying emissions as a function of canopy light extinction (Bryan et al. Forthcoming). Though many studies report extensive inventories of BVOC emissions for a wide range of tree species (Guenther, Zimmerman, and Wildermuth 1994; Kesselmeier and Staudt 1999; Steiner and Goldstein 2007; Warneke et al. 2010), such studies report single values for each BVOC and tree species for the forest site of interest. Since emissions are known to vary on a site-by-site basis, future research should entail additional inventory development of unexplored biomes, followed by a multi-site synthesis of BVOC emissions from a diverse set of forest ecosystem types. 
Discrepancies between model simulations and field observations of oxidants and BVOC oxidation products highlight the need to better understand BVOC oxidation in forest canopies. Current models have difficulty simulating the $\mathrm{OH}$ radical in remote forest environments where vegetation plays an important role in $\mathrm{OH}$ regulation. For example, if BVOC emissions from the forest canopy are very high, then they can deplete $\mathrm{OH}$ concentrations in the troposphere. In fact, most models predict this drawdown of $\mathrm{OH}$ that cannot be confirmed with observations. Models generally underestimate $\mathrm{OH}$ concentrations (Tan et al. 2001; Lelieveld et al. 2008), suggesting either over-depletion in atmospheric chemistry models or a missing in-canopy source. Lelieveld et al. (2008) propose an $\mathrm{OH}$ recycling pathway that avoids $\mathrm{OH}$ depletion, which they apply in models of BVOC-rich tropical rainforests. Models also do not capture long-range horizontal transport from isoprene-poor regions (Sillman et al. 2002) or downward mixing of VOC-clean air from the free atmosphere (Hurst et al. 2001) that may reduce OH loss. Additional $\mathrm{OH}$ sources from terpene dissociation via ozone reaction (Faloona et al. 2001) may also account for the underestimation of $\mathrm{OH}$. While underestimated concentrations suggest a missing $\mathrm{OH}$ source in models, models also underestimate $\mathrm{OH}$ reactivity within the canopy (Di Carlo et al. 2004), which suggests a missing modeled sink of $\mathrm{OH}$ as well. Di Carlo et al. (2004) hypothesize that forest emissions contain VOCs that have yet to be identified and accounted for in atmospheric chemistry models; however, more recent studies suggest that the $\mathrm{OH}$ reactivity can be accounted for by including the oxidation of secondary VOCs discussed above (Kim et al. 2011).

While many past studies have attributed these differences to chemistry, it is also possible that atmospheric models do not accurately capture the vertical mixing of BVOCs. Observational and modeling studies alike point to a need for an improved turbulence characterization and representation in model parameterizations (Hurst et al. 2001; Horiguchi et al. 2010; Bryan et al. 2012). In particular, models neglect the erratic canopy-scale eddies frequently observed in tall plant stands (Finnigan 2000), yet these phenomena contribute around 50 percent or more to the total heat fluxes out of the canopy (Steiner et al. 2011). Bryan et al. (2012) applied the Canopy Atmospheric Chemistry Emission Model (CACHE, Forkel et al. 2006) to observations from CABINEX, finding that near-canopy turbulence outweighs chemistry in modulating forest-atmosphere exchange. This was realized by contrasting two turbulence schemes with two chemistry schemes. Overall magnitudes and the diel patterns of BVOC concentrations were vastly improved when the authors used an alternate turbulence scheme that was driven partially by observations near the canopy. Changing the chemical mechanism to one that included more de- 
tailed isoprene degradation (Geiger et al. 2003; Bryan et al. 2012) yielded negligible change in BVOC concentrations and fluxes out of the forest.

Above the canopy, robust observations of turbulence quantities are often insufficient due to measurement limitations, posing a challenge for model evaluation and validation in multiple locations. Observational data within the canopy are also limited, and more observations are required at multiple sites to capture the complexities of in-canopy turbulence. These data are necessary for characterizing the efficiency of forest-atmosphere BVOC exchange over a wide array of forest types, data that are especially important given the similar timescales of BVOC oxidation and turbulent transport.

To date, our understanding of forest-atmosphere exchange derives from studies performed on the local scale (i.e., for a single forest site). Future work is needed to bridge the gap between local-scale forest-atmosphere exchange and regional-scale ozone formation. A multi-site synthesis of the forest chemistry observations from various ecosystems would help identify differences in forest-atmosphere exchange across a variety of ecosystem types. Secondly, existing findings, particularly those from a multi-site synthesis, should be incorporated into a global or regional climatechemistry model, with which the sensitivity of large-scale ozone concentrations to in-canopy processes can be assessed. Future work could include interdisciplinary studies that address the combined effects of the processes discussed in this review to develop a more holistic view of biosphere-atmosphere interactions and their role in forest-atmosphere BVOC exchange.

\section{Concluding Remarks}

Vegetation sustains human life through its contributions to atmospheric oxygen, the water cycle, and removal of greenhouse gases. Policies to restrict or minimize deforestation in order to preserve these benefits are critical to the continued existence of a sustainable world. However, the net benefit of forested ecosystems should be balanced with an understanding of the contribution of reactive carbon from vegetation and its influence on air quality. Mitigating these effects requires restricting the emission of anthropogenic precursors, especially in regions undergoing landcover transformation and urbanization. Additionally, land-cover-change projects to address carbon sequestration and biofuel production should consider the BVOC emissions of these vegetation species to preclude the large addition of reactive carbon to the atmosphere. To adequately establish controls on emissions, understand- 
ing the natural processes that drive biogenic precursors and their role in air quality is critical. Any and all sustainability efforts aimed at the reduction of tropospheric ozone production should consider this research and attempt to include an understanding of this science in a holistic and sustainable manner.

\section{Acknowledgements}

We thank several colleagues for providing data obtained during the CABINEX 2009 field campaign: Barry Lefer (University of Houston) provided measurements of photosynthetically active radiation and $\mathrm{NO}_{2}$ photolysis frequency, and $\mathrm{B}$. Tom Jobson (Washington State University) provided the isoprene data. We thank the editorial board for inviting us to submit this work and two anonymous reviewers whose generous feedback substantially enhanced this manuscript.

\section{References}

Baldocchi, Dennis D., and Tilden P. Meyers. 1988. "Turbulence Structure in a Deciduous Forest.” Boundary-Layer Meteorology 43 (4):345-364. doi: 10.1007/bf00121712. http://dx.doi. org/10.1007/BF00121712

Bloomer, Bryan J., Jeffrey W. Stehr, Charles A. Piety, Ross J. Salawitch, and Russell R. Dickerson. 2009. "Observed Relationships of Ozone Air Pollution with Temperature and Emissions." Geophysical Research Letters 36 (9):L09803. doi: 10.1029/2009gl037308. http://dx.doi. org/10.1029/2009GL037308

Bryan, A. M., S. B. Bertman, M. A. Carroll, S. Dusanter, G. D. Edwards, R. Forkel, S. Griffith, A. B. Guenther, R. F. Hansen, D. Helmig, B. T. Jobson, F. N. Keutsch, B. L. Lefer, S. N. Pressley, P. B. Shepson, P. S. Stevens, and A. L. Steiner. 2012. "In-Canopy Gas-Phase Chemistry during CABINEX 2009: Sensitivity of a 1-D Canopy Model to Vertical Mixing and Isoprene Chemistry." Atmospheric Chemistry and Physics 12 (18):8829-8849. doi: 10.5194/acp-12-8829-2012. http://dx.doi.org/10.5194/acp-12-8829-2012

Bryan, A. M., B. Hardiman, C. Vogel, G. Bohrer, B. L. Lefer, P. S. Curtis, and A. L. Steiner. Forthcoming. "Sensitivity of Forest-Atmosphere BVOC Exchange to Vertical Heterogeneities in Canopy Structure and Vegetation Composition." Atmospheric Environment.

Carlton, A. G., C. Wiedinmyer, and J. H. Kroll. 2009. "A Review of Secondary Organic Aerosol (SOA) Formation from Isoprene." Atmospheric Chemistry and Physics 9 (14):4987-5005. doi: 10.5194/acp-9-4987-2009. http://dx.doi.org/10.5194/acp-9-4987-2009

Carroll, M. A., S. B. Bertman, and P. B. Shepson. 2001. "Overview of the Program for Research on Oxidants: PHotochemistry, Emissions, and Transport (PROPHET) Summer 1998 Measurements Intensive." Journal of Geophysical Research: Atmospheres 106 (D20):24275-24288. http://dx.doi.org/10.1029/2001JD900189 
Carslaw, N., and D. Carslaw. 2001. "The Gas-Phase Chemistry of Urban Atmospheres." Surveys in Geophysics 22 (1):31-53. http://dx.doi.org/10.1023/A:1010601507383

Chameides, W. L., R. W. Lindsay, J. Richardson, and C. S. Kiang. 1988. "The Role of Biogenic Hydrocarbons in Urban Photochemical Smog: Atlanta as a Case Study." Science 241 (4872):1473-1475. http://dx.doi.org/10.1126/science.3420404

Collineau, Serge, and Yves Brunet. 1993a. "Detection of Turbulent Coherent Motions in a Forest Canopy Part I: Wavelet Analysis.” Boundary-Layer Meteorology 65 (4):357-379. doi: 10.1007/ bf00707033.

1993b. "Detection of Turbulent Coherent Motions in a Forest Canopy Part II: Timescales and Conditional Averages." Boundary-Layer Meteorology 66 (1-2):49-73. doi: 10.1007/ bf00705459. http://dx.doi.org/10.1007/BF00705459

Day, D. A., D. K. Farmer, A. H. Goldstein, P. J. Wooldridge, C. Minejima, and R. C. Cohen. 2009. "Observations of $\mathrm{NO}_{x}, \sum \mathrm{PNs}, \sum \mathrm{ANs}$, and $\mathrm{HNO}_{3}$ at a Rural Site in the California Sierra Nevada Mountains: Summertime Diurnal Cycles." Atmospheric Chemistry and Physics 9 (14):4879-4896. doi: 10.5194/acp-9-4879-2009. http://dx.doi.org/10.5194/acp-94879-2009

Di Carlo, P., W. H. Brune, M. Martinez, H. Harder, R. Lesher, X. R. Ren, T. Thornberry, M. A. Carroll, V. Young, P. B. Shepson, D. Riemer, E. Apel, and C. Campbell. 2004. "Missing $\mathrm{OH}$ Reactivity in a Forest: Evidence for Unknown Reactive Biogenic VOCs." Science 304 (5671):722-725. http://dx.doi.org/10.1126/science.1094392

DiGangi, J. P., E. S. Boyle, T. Karl, P. Harley, A. Turnipseed, S. Kim, C. Cantrell, R. L. Maudlin Iii, W. Zheng, F. Flocke, S. R. Hall, K. Ullmann, Y. Nakashima, J. B. Paul, G. M. Wolfe, A. R. Desai, Y. Kajii, A. Guenther, and F. N. Keutsch. 2011. "First Direct Measurements of Formaldehyde Flux via Eddy Covariance: Implications for Missing In-Canopy Formaldehyde Sources." Atmospheric Chemistry and Physics 11 (20):10565-10578. doi: 10.5194/acp-11-10565-2011. http://dx.doi.org/10.5194/acp-11-10565-2011

Dudareva, Natalia, and Eran Pichersky. 2000. "Biochemical and Molecular Genetic Aspects of Floral Scents.” Plant Physiology 122 (3):627-634. doi: 10.1104/pp.122.3.627. http://dx.doi. org/10.1104/pp.122.3.627

Fall, Ray, and Russell K. Monson. 1992. "Isoprene Emission Rate and Intercellular Isoprene Concentration as Influenced by Stomatal Distribution and Conductance." Plant Physiology 100 (2):987-992. doi: 10.1104/pp.100.2.987. http://dx.doi.org/10.1104/pp.100.2.987

Fall, Ray, and Mary C. Wildermuth. 1998. "Isoprene Synthase: From Biochemical Mechanism to Emission Algorithm.” Journal of Geophysical Research: Atmospheres 103 (D19):25599-25609. doi: 10.1029/98jd00808. http://dx.doi.org/10.1029/98JD00808

Faloona, I., D. Tan, W. Brune, J. Hurst, D. Barket, T. L. Couch, P. Shepson, E. Apel, D. Riemer, T. Thornberry, M. A. Carroll, S. Sillman, G. J. Keeler, J. Sagady, D. Hooper, and K. Paterson. 2001. "Nighttime Observations of Anomalously High Levels of Hydroxyl Radicals above a Deciduous Forest Canopy." Journal of Geophysical Research: Atmospheres 106 (D20):2431524333. http://dx.doi.org/10.1029/2000JD900691

Finkelstein, PeterL., Thomas G. Ellestad, John F. Clarke, Tilden P. Meyers, Donna B. Schwede, Eric O. Hebert, and Julie A. Neal. 2000. "Ozone and Sulfur Dioxide Dry Deposition to Forests: Observations and Model Evaluation.” Journal of Geophysical Research: Atmospheres 105 (D12):1536515377. doi: 10.1029/2000jd900185. http://dx.doi.org/10.1029/2000JD900185 
Finnigan, J. 2000. “Turbulence in Plant Canopies.” Annual Review of Fluid Mechanics 32:519-571. http://dx.doi.org/10.1146/annurev.fluid.32.1.519

Forkel, R., O. Klemm, M. Graus, B. Rappengluck, W. R. Stockwell, W. Grabmer, A. Held, A. Hansel, and R. Steinbrecher. 2006. "Trace Gas Exchange and Gas Phase Chemistry in a Norway Spruce Forest: A Study with a Coupled 1-Dimensional Canopy Atmospheric Chemistry Emission Model." Atmospheric Environment 40:S28-S42. doi: 10.1016/j.atmosenv.2005.11.070. http://dx.doi.org/10.1016/j.atmosenv.2005.11.070

Fuentes, Jose D., M. Lerdau, R. Atkinson, D. Baldocchi, J. W. Bottenheim, P. Ciccioli, B. Lamb, C. Geron, L. Gu, and A. Guenther. 2000. "Biogenic Hydrocarbons in the Atmospheric Boundary Layer: A Review." Bulletin of the American Meteorological Society 81 (7):1537-1576. http:// dx.doi.org/10.1175/1520-0477(2000)081<1537:BHITAB>2.3.CO;2

Fuentes, Jose D., Daniel Wang, Dave R. Bowling, Mark Potosnak, Russell K. Monson, Wendy S. Goliff, and William R. Stockwell. 2007. "Biogenic Hydrocarbon Chemistry within and Above a Mixed Deciduous Forest." Journal of Atmospheric Chemistry 56 (2):165-185. doi: 10.1007/ s10874-006-9048-4. http://dx.doi.org/10.1007/s10874-006-9048-4

Ganzeveld, L., G. Eerdekens, G. Feig, H. Fischer, H. Harder, R. Königstedt, D. Kubistin, M. Martinez, F. X. Meixner, H. A. Scheeren, V. Sinha, D. Taraborrelli, J. Williams, J. Vilá-Guerau de Arellano, and J. Lelieveld. 2008. "Surface and Boundary Layer Exchanges of Volatile Organic Compounds, Nitrogen Oxides and Ozone during the GABRIEL Campaign." Atmospheric Chemistry and Physics 8 (20):6223-6243. doi: 10.5194/acp-8-6223-2008. http://dx.doi. org/10.5194/acp-8-6223-2008

Geiger, H., I. Barnes, J. Bejan, T. Benter, and M. Spittler. 2003. "The Tropospheric Degradation of Isoprene: An Updated Module for the Regional Atmospheric Chemistry Mechanism." Atmospheric Environment 37 (11):1503-1519. doi: 10.1016/S1352-2310(02)01047-6. http:// dx.doi.org/10.1016/S1352-2310(02)01047-6

Guenther, Alex B., C. N. Hewitt, D. Erickson, R. Fall, C. Geron, T. Graedel, P. Harley, L. Klinger, M. Lerdau, W. A. Mckay, T. Pierce, B. Scholes, R. Steinbrecher, R. Tallamraju, J. Taylor, and P. Zimmerman. 1995. "A Global-Model of Natural Volatile Organic-Compound Emissions." Journal of Geophysical Research: Atmospheres 100 (D5):8873-8892. http://dx.doi. org/10.1029/94JD02950

Guenther, Alex B., T. Karl, P. Harley, C. Wiedinmyer, P. I. Palmer, and C. Geron. 2006. "Estimates of Global Terrestrial Isoprene Emissions using MEGAN (Model of Emissions of Gases and Aerosols from Nature)." Atmospheric Chemistry and Physics 6:3181-3210. http://dx.doi. org/10.5194/acp-6-3181-2006

Guenther, Alex B., Russell K. Monson, and Ray Fall. 1991. "Isoprene and Monoterpene Emission Rate Variability: Observations with Eucalyptus and Emission Rate Algorithm Development." Journal of Geophysical Research: Atmospheres 96 (D6):10799-10808. doi: 10.1029/91jd00960. http://dx.doi.org/10.1029/91JD00960

Guenther, Alex B., Patrick Zimmerman, and Mary Wildermuth. 1994. "Natural Volatile Organic Compound Emission Rate Estimates for U.S. Woodland Landscapes." Atmospheric Environment 28 (6):1197-1210. http://dx.doi.org/10.1016/1352-2310(94)90297-6

Hallquist, M., J. C. Wenger, U. Baltensperger, Y. Rudich, D. Simpson, M. Claeys, J. Dommen, N. M. Donahue, C. George, A. H. Goldstein, J. F. Hamilton, H. Herrmann, T. Hoffmann, Y. Iinuma, M. Jang, M. E. Jenkin, J. L. Jimenez, A. Kiendler-Scharr, W. Maenhaut, G. McFig- 
gans, Th F. Mentel, A. Monod, A. S. H. Prévôt, J. H. Seinfeld, J. D. Surratt, R. Szmigielski, and J. Wildt. 2009. "The Formation, Properties and Impact of Secondary Organic Aerosol: Current and Emerging Issues." Atmospheric Chemistry and Physics 9 (14):5155-5236. doi: 10.5194/acp-9-5155-2009. http://dx.doi.org/10.5194/acp-9-5155-2009

Heald, C. L., D. K. Henze, L. W. Horowitz, J. Feddema, J. F. Lamarque, A. Guenther, P. G. Hess, F. Vitt, J. H. Seinfeld, A. H. Goldstein, and I. Fung. 2008. "Predicted Change in Global Secondary Organic Aerosol Concentrations in Response to Future Climate, Emissions, and Land Use Change." Journal of Geophysical Research: Atmospheres 113 (D5):D05211. doi: 10.1029/2007jd009092. http://dx.doi.org/10.1029/2007JD009092

Hogg, Alan, Johan Uddling, David Ellsworth, Mary Anne Carroll, Shelley Pressley, Brian Lamb, and Christoph Vogel. 2007. "Stomatal and Non-Stomatal Fluxes of Ozone to a Northern Mixed Hardwood Forest.” Tellus B 59 (3):514-525. doi: 10.1111/j.1600-0889.2007.00269.x. http://dx.doi.org/10.1111/j.1600-0889.2007.00269.x

Horiguchi, Mitsuaki, Taiichi Hayashi, Hiroyuki Hashiguchi, Yoshiki Ito, and Hiromasa Ueda. 2010. "Observations of Coherent Turbulence Structures in the Near-Neutral Atmospheric Boundary Layer." Boundary-Layer Meteorology 136 (1):25-44. doi: 10.1007/s10546-0109500-5. http://dx.doi.org/10.1007/s10546-010-9500-5

Hurst, Julia M., Dennis J. Barket, Orlando Herrera-Gomez, Tara L. Couch, Paul B. Shepson, I. Faloona, D. Tan, W. Brune, H. Westberg, B. Lamb, T. Biesenthal, V. Young, Allen Goldstein, J. W. Munger, T. Thornberry, and M. A. Carroll. 2001. "Investigation of the Nighttime Decay of Isoprene." Journal of Geophysical Research: Atmospheres 106 (D20):24335-24346. doi: 10.1029/2000jd900727. http://dx.doi.org/10.1029/2000JD900727

Karl, T., P. Harley, L. Emmons, B. Thornton, A. Guenther, C. Basu, A. Turnipseed, and K. Jardine. 2010. "Efficient Atmospheric Cleansing of Oxidized Organic Trace Gases by Vegetation." Science 330 (6005):816-819. doi: 10.1126/science.1192534. http://dx.doi.org/10.1126/science. 1192534

Kesselmeier, J., and M. Staudt. 1999. "Biogenic Volatile Organic Compounds (VOC): An Overview on Emission, Physiology and Ecology." Journal of Atmospheric Chemistry 33 (1):23-88. doi: 10.1023/a:1006127516791. http://dx.doi.org/10.1023/A:1006127516791

Kim, S., A. Guenther, T. Karl, and J. Greenberg. 2011. "Contributions of Primary and Secondary Biogenic VOC Tototal OH Reactivity during the CABINEX (Community AtmosphereBiosphere INteractions Experiments)-09 Field Campaign.” Atmospheric Chemistry and Physics no. 11 (16):8613-8623. doi: Doi 10.5194/Acp-11-8613-2011.

Knohl, Alexander, and Dennis D. Baldocchi. 2008. "Effects of Diffuse Radiation on Canopy Gas Exchange Processes in a Forest Ecosystem." Journal of Geophysical Research: Biogeosciences 113:G02023. doi: 10.1029/2007jg000663. http://dx.doi.org/10.1029/2007JG000663

Krol, M. C., M. J. Molemaker, and J. V. G. de Arellano. 2000. "Effects of Turbulence and Heterogeneous Emissions on Photochemically Active Species in the Convective Boundary Layer." Journal of Geophysical Research: Atmospheres 105 (D5):6871-6884. http://dx.doi. org/10.1029/1999JD900958

Lelieveld, J., T. M. Butler, J. N. Crowley, T. J. Dillon, H. Fischer, L. Ganzeveld, H. Harder, M. G. Lawrence, M. Martinez, D. Taraborrelli, and J. Williams. 2008. "Atmospheric Oxidation Capacity Sustained by a Tropical Forest.” Nature 452 (7188):737-740. doi: 10.1038/ nature06870. http://dx.doi.org/10.1038/nature06870 
Lerdau, Manuel, Alex Guenther, and Russ Monson. 1997. "Plant Production and Emission of Volatile Organic Compounds.” BioScience 47 (6):373-383. doi: 10.2307/1313152. http:// dx.doi.org/10.2307/1313152

Logan, J. A. 1985. "Tropospheric Ozone-Seasonal Behavior, Trends, and Anthropogenic Influence." Journal of Geophysical Research: Atmospheres 90 (Nd6):10463-10482.

Loreto, F., P. Ciccioli, A. Cecinato, E. Brancaleoni, M. Frattoni, C. Fabozzi, and D. Tricoli. 1996. "Evidence of the Photosynthetic Origin of Monoterpenes Emitted by Quercus ilex L. Leaves by 13C Labeling.” Plant Physiology 110 (4):1317-1322. doi: 10.1104/pp.110.4.1317.

Loreto, Francesco, and Violeta Velikova. 2001. "Isoprene Produced by Leaves Protects the Photosynthetic Apparatus against Ozone Damage, Quenches Ozone Products, and Reduces Lipid Peroxidation of Cellular Membranes." Plant Physiology 127 (4):1781-1787. doi: 10.1104/ pp.010497. http://dx.doi.org/10.1104/pp.010497

Molemaker, M. J., and J. V. G. de Arellano. 1998. "Control of Chemical Reactions by Convective Turbulence in the Boundary Layer." Journal of the Atmospheric Sciences 55 (4):568-579. http:// dx.doi.org/10.1175/1520-0469(1998)055<0568:COCRBC>2.0.CO;2

Monson, Russell K., Charles H. Jaeger, William W. Adams, Edward M. Driggers, Gary M. Silver, and Ray Fall. 1992. "Relationships among Isoprene Emission Rate, Photosynthesis, and Isoprene Synthase Activity as Influenced by Temperature.” Plant Physiology 98 (3):1175-1180. doi: 10.1104/pp.98.3.1175. http://dx.doi.org/10.1104/pp.98.3.1175

Muller, Cornelius H. 1966. "The Role of Chemical Inhibition (Allelopathy) in Vegetational Composition." Bulletin of the Torrey Botanical Club 93 (5):332-351. doi: 10.2307/2483447. http:// dx.doi.org/10.2307/2483447

Phillips, Michael A., and Rodney B. Croteau. 1999. "Resin-Based Defenses in Conifers." Trends in plant science 4 (5):184-190. http://dx.doi.org/10.1016/S1360-1385(99)01401-6

Raupach, M. R., J. J. Finnigan, and Y. Brunet. 1996. "Coherent Eddies and Turbulence in Vegetation Canopies: The Mixing-Layer Analogy." Boundary-Layer Meteorology 78 (3-4):351-382. http://dx.doi.org/10.1007/BF00120941

Sharkey, Thomas D., and Eric L. Singsaas. 1995. "Why Plants Emit Isoprene." Nature 374 (6525):769-769. http://dx.doi.org/10.1038/374769a0

Sharkey, Thomas D., Eric L. Singsaas, Peter J. Vanderveer, and Chris Geron. 1996. "Field Measurements of Isoprene Emission from Trees in Response to Temperature and Light." Tree Physiology 16 (7):649-654. doi: 10.1093/treephys/16.7.649. http://dx.doi.org/10.1093/treephys/16.7.649

Sharkey, Thomas D., Amy E. Wiberley, and Autumn R. Donohue. 2008. "Isoprene Emission from Plants: Why and How." Annals of Botany 101 (1):5-18. doi: 10.1093/aob/mcm240. http:// dx.doi.org/10.1093/aob/mcm240

Sillman, S. 1999. "The Relation between Ozone, $\mathrm{NO}_{\mathrm{x}}$ and Hydrocarbons in Urban and Polluted Rural Environments." Atmospheric Environment 33 (12):1821-1845. http://dx.doi. org/10.1016/S1352-2310(98)00345-8

Sillman, S., M. A. Carroll, T. Thornberry, B. K. Lamb, H. Westberg, W. H. Brune, I. Faloona, D. Tan, P. B. Shepson, A. L. Sumner, D. R. Hastie, C. M. Mihele, E. C. Apel, D. D. Riemer, and R. G. Zika. 2002. "Loss of Isoprene and Sources of Nighttime OH Radicals at a Rural Site in the United States: Results from Photochemical Models." Journal of Geophysical Research: Atmospheres 107 (D5):4043-4057. doi: 10.1029/2001JD000449. http://dx.doi. org/10.1029/2001JD000449 
Smiatek, Gerhard, and Rainer Steinbrecher. 2006. "Temporal and Spatial Variation of Forest VOC Emissions in Germany in the Decade 1994-2003.” Atmospheric Environment 40, Supplement 1 (0):166-177. http://dx.doi.org/10.1016/j.atmosenv.2005.11.071

Steiner, Allison L., and Allen H. Goldstein. 2007. "Biogenic VOCs." In Volatile Organic Compounds in the Atmosphere, edited by Ralf Koppmann, 82-128. Oxford, UK: Blackwell Publishing Ltd. http://dx.doi.org/10.1002/9780470988657.ch3

Steiner, Allison L., S. N. Pressley, A. Botros, E. Jones, S. H. Chung, and S. L. Edburg. 2011. "Analysis of Coherent Structures and Atmosphere-Canopy Coupling Strength during the CABINEX Field Campaign: Implications for Atmospheric Chemistry." Atmospheric Chemistry and Physics Discussions 11:21013-21054. http://dx.doi.org/10.5194/acpd-11-21013-2011

Steiner, Allison L., Shaheen Tonse, Ronald C. Cohen, Allen H. Goldstein, and Robert A. Harley. 2006. "Influence of Future Climate and Emissions on Regional Air Quality in California." Journal of Geophysical Research: Atmospheres 111 (D18):D18303. doi: 10.1029/2005jd006935. http://dx.doi.org/10.1029/2005JD006935

Stroud, C., P. Makar, T. Karl, A. Guenther, C. Geron, A. Turnipseed, E. Nemitz, B. Baker, M. Potosnak, and J. D. Fuentes. 2005. "Role of Canopy-Scale Photochemistry in Modifying BiogenicAtmosphere Exchange of Reactive Terpene Species: Results from the CELTIC Field Study." Journal of Geophysical Research: Atmospheres 110:D00F18. doi: 10.1029/2005JD005775. http://dx.doi.org/10.1029/2005JD005775

Stull, R. B. 1988. An Introduction to Boundary Layer Meteorology. Dordrecht, The Netherlands: Kluwer Academic Publishers. http://dx.doi.org/10.1007/978-94-009-3027-8

Sumner, A. L., P. B. Shepson, T. L. Couch, T. Thornberry, M. A. Carroll, S. Sillman, M. Pippin, S. Bertman, D. Tan, I. Faloona, W. Brune, V. Young, O. Cooper, J. Moody, and W. Stockwell. 2001. "A Study of Formaldehyde Chemistry above a Forest Canopy." Journal of Geophysical Research: Atmospheres 106 (D20):24387-24405. http://dx.doi.org/10.1029/2000JD900761

Tan, D., I. Faloona, J. B. Simpas, W. Brune, P. B. Shepson, T. L. Couch, A. L. Sumner, M. A. Carroll, T. Thornberry, E. Apel, D. Riemer, and W. Stockwell. 2001. "HOx Budgets in a Deciduous Forest: Results from the PROPHET Summer 1998 Campaign.” Journal of Geophysical Research: Atmospheres 106 (D20):24407-24427. http://dx.doi.org/10.1029/2001JD900016

Tawfik, Ahmed B., Reto Stöckli, Allen Goldstein, Shelley Pressley, and Allison L. Steiner. 2012. "Quantifying the Contribution of Environmental Factors to Isoprene Flux Interannual Variability." Atmospheric Environment 54 (0):216-224. http://dx.doi.org/10.1016/j.atmosenv.2012.02.018

Tingey, David T., Marybeth Manning, Louis C. Grothaus, and Walter F. Burns. 1979. "The Influence of Light and Temperature on Isoprene Emission Rates from Live Oak." Physiologia Plantarum 47 (2):112-118. doi: 10.1111/j.1399-3054.1979.tb03200.x. http://dx.doi. org/10.1111/j.1399-3054.1979.tb03200.x

Warneke, C., J. A. de Gouw, L. Del Negro, J. Brioude, S. McKeen, H. Stark, W. C. Kuster, P. D. Goldan, M. Trainer, F. C. Fehsenfeld, C. Wiedinmyer, A. B. Guenther, A. Hansel, A. Wisthaler, E. Atlas, J. S. Holloway, T. B. Ryerson, J. Peischl, L. G. Huey, and A. T. Case Hanks. 2010. "Biogenic Emission Measurement and Inventories Determination of Biogenic Emissions in the Eastern United States and Texas and Comparison with Biogenic Emission Inventories." Journal of Geophysical Research: Atmospheres 115:D00F18. doi: 10.1029/2009jd012445. http://dx.doi.org/10.1029/2009JD012445

Wesely, M. L. 1989. "Parameterization of Surface Resistances to Gaseous Dry Deposition in 
Regional-Scale Numerical Models." Atmospheric Environment 23 (6):1293-1304. http:// dx.doi.org/10.1016/0004-6981(89)90153-4

Wolfe, G. M., J. A. Thornton, N. C. Bouvier-Brown, A. H. Goldstein, J. H. Park, M. Mckay, D. M. Matross, J. Mao, W. H. Brune, B. W. LaFranchi, E. C. Browne, K. E. Min, P. J. Wooldridge, R. C. Cohen, J. D. Crounse, I. C. Faloona, J. B. Gilman, W. C. Kuster, J. A. de Gouw, A. Huisman, and F. N. Keutsch. 2011. "The Chemistry of Atmosphere-Forest Exchange (CAFE) Model - Part 2: Application to BEARPEX-2007 Observations." Atmospheric Chemistry and Physics 11 (3):1269-1294. doi: 10.5194/acp-11-1269-2011. http://dx.doi.org/10.5194/acp11-1269-2011 